\title{
Implementation of project based learning in mechanical engineering education to enhance students' interest and enthusiasm
}

\author{
N.S. Chandrashekhar, Chithra Biju Menon \\ Mechanical Department, K.J. Somaiya College of Engineering, Vidyavihar, Mumbai 400077 ,India \\ nschandrashekhar@somaiya.edu, chitramenon@somaiya.edu
}

\begin{abstract}
The traditional classroom teaching technique which is commonly used in Engineering Education does not focus on what the students have learnt. As a result of this the students lose interest in the course. Project based learning on the other hand gives the student an opportunity to explore more on the concepts and apply the same while working on the project. Project based learning has been implemented in the course of Theory of Machines I which is offered to the second year students of the Mechanical Engineering Program in the autonomous curriculum of K.J.Somaiya College of Engineering. The 'Do it yourself' mini projects were assigned as a part of internal assessment to all the students of the second year. This paper evaluates the impact of project based learning on inculcating interest in the course, improving the performance in examination and course outcome. The improvement in the test marks has been analysed statistically. The feedback taken from the students has also been analysed. The project based learning method is useful in retaining the interest of the students in a core course.
\end{abstract}

Keywords: Project based learning, Do it yourself, interest, enthusiasm, autonomous

\section{Introduction}

The traditional teaching methods are teacher centric where very little focus is on what is learnt by the students. Projectbased learning employs an inductive, learner-centred approach to the acquisition of knowledge and skills. It is underpinned by constructivist theory, which assumes that all new understandings are built upon previous knowledge and that the interweaving of knowledge and practical skills can help students to consolidate their understandings. Project-based learning encourage students to learn together and problem-solve collectively. This process is, in itself, generative and that learning is reinforced when students teach each other. Project-based learning gives students the opportunity to develop their communication, problemsolving and team-working skills which will be relevant in their future careers (Joyce et al., 2013)(Thomas, 2000)(Hung, 2011). In project based learning (individual or group) method, the students feel empowered when they apply critical thinking to solve the problems. The projects motivate the students and improve their interest since it is provocative and fun (Guzelis, 2006) (Gavin, 2011) (Mills and Treagust, 2003). Project based learning include working on complex tasks that involve the students in design, problem- solving, decision making where the students work autonomously, shifting the focus from teacher centric to student centric (Fini et al., 2018) (Constans and Kadlowec, 2011) (Zhu et al., 2019).

K.J. Somaiya College of Engineering, Vidyavihar, Mumbai which is affiliated to University of Mumbai since 1983 has been given autonomy in 2014. The autonomous status gave the system the flexibility to modify the content of syllabus, as per the need. In this work, the effect of introducing project based learning in the course of Theory of Machines has been studied. This basic course is offered to second year engineering students. The credits assigned to the course are 4 . It comprises of 3 hours of lectures and 2 hours of tutorials. The evaluation scheme consists of 15 marks of test 1 and test 2 each, internal assessment 10 marks, term work 25 marks and end semester examination of 60 marks. The time gap between the test 1 and test 2 is 6 weeks approximately. It deals with the motion analysis of various mechanisms used in practice. In the traditional system the students were given set of questions to be solved as assignments. But it was observed that it is very difficult to keep the interest and enthusiasm of the students in the course alive through written assignments. The aim of introducing the mini projects as an internal assessment component is to use the active learning method and make it student centric. This would improve the overall interest and enthusiasm of the students ( Jollands et al., 2012). The students can apply the concepts which they learnt in the classroom practically in their projects.

\section{Methodology}

In order to implement the "Do it yourself project" in a structured way, the following method odology was used:

The complete activity was divided into 3 sub activities A,B,C which consists of three steps for a span of 15 weeks.

\section{A. Pre project activity:(Duration 6 weeks)}

The pre project activity focussed on preparing the students for taking up the mini project work. It included activities to expose the students to the concepts of kinematic analysis of mechanisms and also gave them a chance to explore the applications. 
Step1: Expose: The students were introduced to the concepts, analysis and applications of various mechanisms through class room teaching of 3 hours session per week. During the practical sessions the students performed the motion analysis using softwares like Autocad and Solidworks.

Step 2: Explore: For better understanding of the course the students were asked to explore the various mechanisms given in the textbooks. Also they were asked to find out the available mechanisms used in the different engineering sectors. Each student was asked to prepare a presentation on any one mechanism used in the sectors of manufacturing, agriculture etc.

\section{B. Project activity:(Duration 6 weeks)}

The Project activity focussed on giving students an experience of working on projects which will make their concepts stronger. Also it would improve their project management skills.

Step 3: Experience: In order to actually begin their journey of hands on experience on working on the project, the list of projects was shared with the students. In the academic year 2017-2018 and 2018-2019 we included the online links of the simulation videos of mechanisms. 40 groups per year (2016-2017, 2017-2018, 2018-2019), each group having 4 students, participated in this project. Different projects were assigned to each group and they were asked to fabricate a working model for the same. Time of six weeks was allotted to each group to complete the activity. Sample projects for the three years have been shown in Figure 1 which includes Deltoid mechanism, Andrew variable stroke mechanism and External swing mechanism.

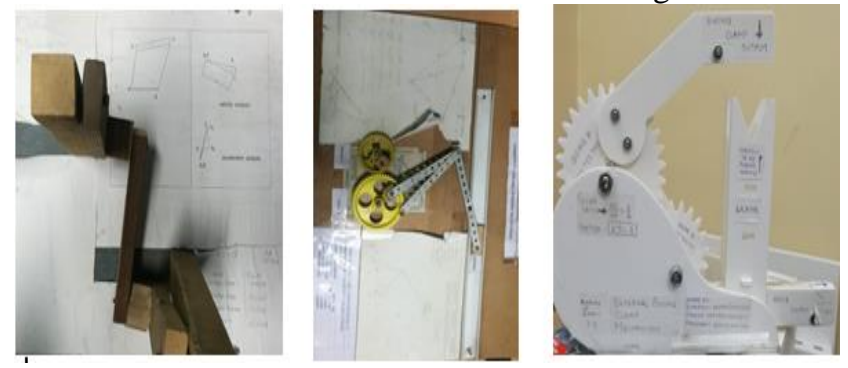

Figure 1. Sample Projects for the three years(Deltoid mechanism: 20162017, Andrew variable stroke mechanism : 2017-2018 and External swing mechanism: 2018-2019)

C. Post Project evaluation and feedback analysis:(Duration 3 weeks)

The students exhibited their model along with the kinematic analysis of the mechanism involved, which was evaluated by the course teachers. The criteria of evaluation of the projects were design, analysis and fabrication of robust system.

Qualitative and quantitative analysis of the effect of introducing this activity on the student performance was done on the basis of the following parameters:

a. Feedback on the experience of working on mini projects from the students for 3 years. b. Term tests comprised of 3 questions of 10 marks each. The performance of the students in Test 1 and Test 2 was compared for 3 consecutive years.

c. The attainment of Course outcome 3 i.e. (Design and fabricate simple mechanisms using kinematics) for 3 consecutive years was observed.

\section{Results and Discussion}

The number of students who participated in the activity was 156 in the years 2016-17 and 2018-19 while it was 157 in the year 2017-18. Feedback on the experience of working on mini projects from the students for 3 years was analysed. Five questions were framed and the rating of the students has been taken on the scale of 1 (minimum) to 5(maximum). The results for the same have been elaborated in Table 2.On an average for three years $79 \%$ of the students who responded to the feedback strongly agreed that mini project helped them in learning the course content and were also of the opinion that the technique was better compared to classroom teaching. Around $69 \%$ of the students agreed that the activity gave them an experience of project management. On an average $48 \%$ of the students agreed that the activity improved their performance in tests and exams. $74 \%$ of the students also agreed that the activity increased their overall interest in the course.

The comparison of the test 1 and test 2 marks for all the three years are given in Figure 2. It indicates that the number of students getting more than 25 marks out of 30 marks is more in test 2 as compared to test 1 . The statistical analysis for improvement in test marks was also performed, the results of which are given in Table 1 which indicates an increase in test marks of students.

Since the actual mini project activity begins after the test 1 it can be supposed that one of the factors that is contributing to the improvement in the test performance may be the involvement of the students in the mini project. Also the $\mathrm{p}$ value obtained from paired $\mathrm{z}$ test is less than 0.05 indicating that the project based learning has improved the test marks. Though the marks obtained by the students are less in 2018-2019 it can be due to the difficulty of the questions in the test of that academic year. For the said course the third course outcome framed in the syllabus is 'The students will be able to design and fabricate simple mechanisms using Kinematics'. The attainment of this course outcome is tabulated in Table 3 . It is observed that the attainment of the course outcome through direct and indirect assessment is consistently high. The projects are kept for display in the department which is used by the faculty as models for explaining the concepts in other courses.

Though the outcomes of implementing the project based learning in the course is appreciable, there were certainly some implementation issues. The most important being convincing the students that though the marks allotted for the activity is less and the time consumed is more, the benefits reaped by the participants would be substantial. Also it is not practically possible for us to provide fund for every project. 
Table 1. Results of statistical analysis of the test performances of the student

\begin{tabular}{|l|l|l|l|l|}
\hline Year & $\begin{array}{l}\text { No of } \\
\text { Students }\end{array}$ & $\begin{array}{l}\text { Mean increase } \\
\text { in marks }\end{array}$ & SD & P value \\
\hline $2016-17$ & 157 & 4.08 & 7.24 & $2.74 \mathrm{E}-07$ \\
\hline $2017-18$ & 156 & 2.87 & 6.59 & $8.73 \mathrm{E}-05$ \\
\hline $2018-19$ & 157 & 6.21 & 7.6 & $4.44 \mathrm{E}-16$ \\
\hline
\end{tabular}
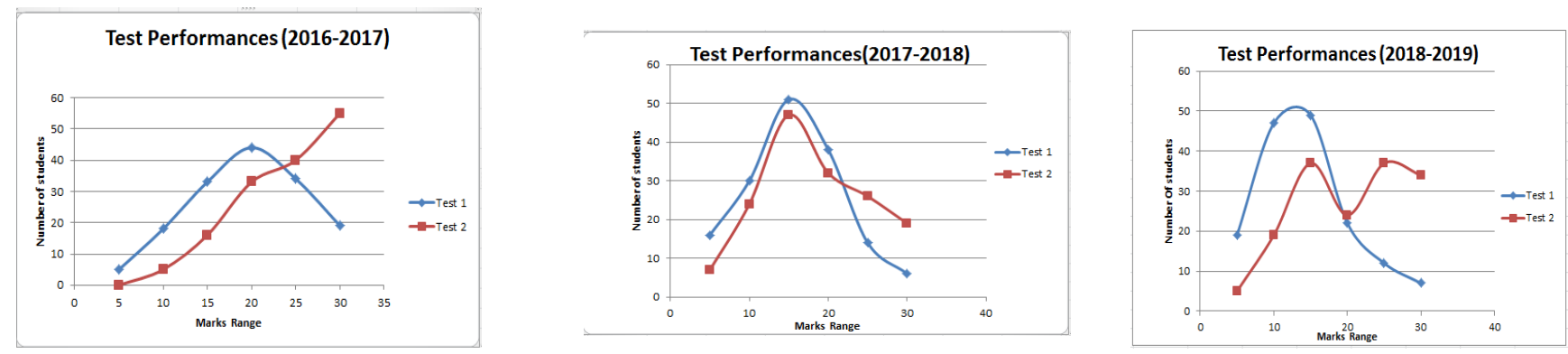

Figure 2. Comparison of Test 1 and Test 2 performances for all the three years

Table 2. Feedback from students for the mini project

\begin{tabular}{|c|c|c|c|c|c|c|c|c|c|c|c|c|c|c|c|}
\hline Year & \multicolumn{5}{|c|}{ 2016-2017 } & \multicolumn{5}{|c|}{ 2017-2018 } & \multicolumn{5}{|c|}{ 2018-2019 } \\
\hline Rating $\rightarrow$ & 1 & 2 & 3 & 4 & 5 & 1 & 2 & 3 & 4 & 5 & 1 & 2 & 3 & 4 & 5 \\
\hline Question & & & & & & & & & & & & & & & \\
\hline $\begin{array}{l}1 \text { Mini Project helped me in } \\
\text { learning the course content }\end{array}$ & 0 & 0 & 27.3 & 54.5 & 18.2 & 0 & 0 & 5.9 & 64.7 & 29.4 & 0 & 5.4 & 21.6 & 43.2 & 29.7 \\
\hline $\begin{array}{l}2 \text { Personally analysing, fabricating } \\
\text { and seeing the output was better } \\
\text { than classroom demonstration by } \\
\text { the instructor. }\end{array}$ & 0 & 0 & 27.3 & 18.2 & 54.5 & 0 & 0 & 17.6 & 23.5 & 58.8 & 0 & 8.1 & 8.1 & 43.2 & 40.5 \\
\hline $\begin{array}{l}3 \text { The mini project helped me } \\
\text { prepare for my test and final exam. }\end{array}$ & 0 & 9.1 & 36.4 & 36.4 & 18.2 & 0 & 5.9 & 47.1 & 35.3 & 11.8 & 19 & 10.8 & 29.7 & 35.1 & 5.4 \\
\hline $\begin{array}{l}4 \text { The mini project gave me an } \\
\text { experience of project management. }\end{array}$ & 0 & 18.2 & 27.3 & 36.4 & 18.2 & 0 & 11.8 & 11.8 & 47.1 & 29.4 & 0 & 5.4 & 18.9 & 45.9 & 29.7 \\
\hline $\begin{array}{l}5 \text { The mini project increased my } \\
\text { overall interest in the course }\end{array}$ & 0 & 0 & 27.3 & 54.5 & 18.2 & 0 & 0 & 17.6 & 47.1 & 35.3 & 8.1 & 8.1 & 16.2 & 37.8 & 29.7 \\
\hline
\end{tabular}


Table 3. CO3 attainment details

\begin{tabular}{|c|c|c|c|}
\hline Year & $\begin{array}{c}\text { Direct } \\
\text { Assessment\%(D) } \\
\text { (Project } \\
\text { Evaluation out } \\
\text { of 10 marks) }\end{array}$ & $\begin{array}{c}\text { Indirect } \\
\text { Assessment\%(I) } \\
\text { (Survey } \\
\text { Questions: I am } \\
\text { able to design a } \\
\text { mechanism, Iam } \\
\text { able to fabricate } \\
\text { a mechanism ) }\end{array}$ & $\begin{array}{c} \\
\text { Average } \\
\text { assessment\%(0.8D } \\
\mathbf{+ ~ 0 . 2 ~ I ) ~}\end{array}$ \\
\hline $2016-$ & 70.84 & 80.44 & 72.76 \\
2017 & & 77.76 & 90.60 \\
\hline $2017-$ & 93.82 & 78.81 & 84.65 \\
2018 & & & \\
\hline $2018-$ & 86.11 & & \\
2019 & & & \\
\hline
\end{tabular}

\section{Conclusion}

The 3 E concept of expose, explore and Experience was implemented in this study. Further practice will lead us to the fourth $\mathrm{E}$ i.e. expertise. The project based learning improves the understanding of the course for the students. This is reflected in their improvement in the performance in examinations. It gives them an exposure to work in a team and enhances their project management skills. It improves their analytical and technical skills thus improving their employability. It has contributed to the overall development of personality of the student. The technique can be used to increase the interest and enthusiasm of the students to learn a core course compared to the traditional classroom teaching approach. Also it has helped the department to have working models for demonstration to the other batches of students.

\section{Acknowledgement}

We would like to acknowledge the continuous motivation and support from the management, Principal and department for innovative practices. We would like to thank them for providing space and facilities to display the projects in the lab for all to learn. We would also like to acknowledge the participation of faculty who has directly or indirectly contributed in the preparation of the course content and in the execution of the various activities related to it. Also, the assistance provided by the workshop to the students in the fabrication process is remarkable.

\section{References}

Constans, E. and Kadlowec, J. (2011, January). Using a project-based learning approach to teach mechanical design to first-year engineering students. In ASEE Annual Conference and Exposition, Conference Proceedings.

Fini, E. H., Awadallah, F., Parast, M. M. and AbuLebdeh, T. (2018). The impact of project-based learning on improving student learning outcomes of sustainability concepts in transportation engineering courses. European Journal of Engineering Education, 43(3), 473-488.

Gavin, K. (2011). Case study of a project-based learning course in civil engineering design. European Journal of Engineering Education, 36(6), 547-558.

Guzelis, C. (2006). An experience on problem based learning in an engineering faculty. Turkish Journal of Electrical Engineering \& Computer Sciences, 14(1), 67-76.

Hung, W. (2011). Theory to reality: A few issues in implementing problem-based learning. Educational Technology Research and Development, 59(4), 529552.

Jollands, M., Jolly, L. and Molyneaux, T. (2012). Project-based learning as a contributing factor to graduates' work readiness. European Journal of Engineering Education, 37(2), 143-154.

Joyce, T., Evans, I., Pallan, W. and Hopkins, C. (2013). A hands-on project-based mechanical engineering design module focusing on sustainability. Engineering Education, 8(1), 65-80.

Mills, J. E. and Treagust, D. F. (2003). Engineering education-Is problem-based or project-based learning the answer. Australasian journal of engineering education, 3(2), 2-16.

Thomas, J. W. (2000). A review of research on projectbased learning.

Zhu, J., Liu, R., Liu, Q., Zheng, T. and Zhang, Z. (2019). Engineering Students' Epistemological Thinking in the Context of Project-Based Learning. IEEE Transactions on Education. 